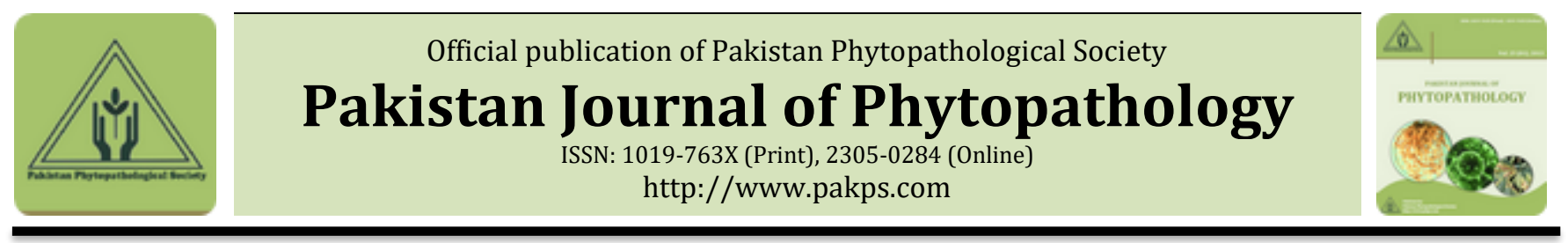

\title{
MANAGING FUSARIUM WILT OF PEA BY UTILIZING DIFFERENT APPLICATION METHODS OF FUNGICIDES
}

\author{
aSaman Aslam, aMuhamamd U. Ghazanfar, bNida Munir, aMuhammad I. Hamid* \\ a Department of Plant Pathology, College of Agriculture, University of Sargodha, Sargodha, 40100, Pakistan. \\ ${ }^{b}$ Department of biotechnology, University of Sargodha, Sargodha, 40100, Pakistan.
}

\begin{abstract}
A B S T R A C T
Fusarium wilt of pea is an ubiquitous disease of pea in all peas growing areas. The disease is able to cause hundred percent yield losses under favorable conditions. Multiple management approaches are in use to control this soil pathogen on different growth stages of crop, in which chemical control is providing quick response. This study was designed to evaluate different fungicides and their application methods to inhibit the pathogenic growth and development. Moreover, minimum effective concentration of fungicides against wilt disease of pea was also evaluated. Both in vitro and in vivo bio assays were designed to test the fungicidal efficacy. During in vitro assay minimum effective concentration of $10 \mathrm{ppm}$ from four fungicides Thiophanate methyl, Acrobat, Matalyxal and Fosetyl aluminium was evaluated. In green house assay flooding method was proved more affective against wilt disease of pea. The fungicides application showed significantly lower disease incidence as compared to untreated control. Acrobate provided more appreciable response to decrease disease incidence during flooding method and Fosetyl aluminum showed good efficiency in inhibition of pathogen during seed treatment and spraying method. Plant growth parameters were also measured and significant improvement was observed in growth response of treated plants as compared to untreated control. The results showed that fungicides can provide efficient control measures against pea wilt disease by utilizing appropriate application method.
\end{abstract}

Keywords: Application methods, Disease incidence, Fungicides, Fusarium wilt.

\section{INTRODUCTION}

Pea (Pisum sativum), a member of legume family used as food, fodder and vegetable for human and animal throughout the world. Pea crop is an important winter season crop throughout the world including Pakistan which necessitate with cool and humid conditions (Sharma, 2011). Grains of pea are full of protein (27.8\%), carbohydrate $(42.65 \%)$, vitamins, minerals and other dietry fibers (Urbano et al., 2003). It is among the most significant legume crop harvested around the world after soya bean, chick pea and groundnut (Foyer et al., 2016). Pea crop was cultivated during 2011- 2012 on 15.8 thousand hectare with 105 thousand tons and

Submitted: April 29, 2019

Revised: May 29, 2019

Accepted for Publication: June 19, 2019

* Corresponding Author:

Email: imran.hamid@uos.edu.pk

(c) 2017 Pak. J. Phytopathol. All rights reserved. average yield of 576 tons per hectare (Pak. Economic Survey, 2017). Pea crop is cultivated throughout Pakistan with production share of Punjab, Sindh, Kpk, Baluchistan was 71.2, 4.7, 12.8 and 11.3 thousand tons, respectively (Pak. Economic Survey, 2017). Despite of efficient nitrogen fixing ability and environmental aspects yield of pea grain is decreasing due to various biotic and abiotic constraints.

The fungal root pathogen Fusarium oxysporum f. sp. pisi causing wilt of pea is responsible for the major losses of pea among other pathogen. Fusarium oxsporum f. sp. pisi has ability to produce deleterious yield losses in pea production all over the world (Dubey et al., 2007). Winter crop is most affected by Fusarium wilt and cause significant losses and it is most prevalent in maximum varieties with yield losses up to $100 \%$ (Persson et al., 1997). Fusarium oxsporum inoculum can survive in field for many years without affected by severe situations and, even, sometime these conditions lead to 
development of new biological strains (Jones et al., 1991).

The aggressive nature of this pathogen in soil made it difficult to control the disease using cultural practices (Sharma et al., 2010). Yet, no efficient and economical means are recommended to ensure the inhibition of Fusarium wilt disease, however, fungicides are the efficient and fastest among them (Moosa et al., 2017). Although disease control through use of synthetic chemical is not environment friendly but due to nonavailability of effective biocontrol mean, we have to depend upon these chemical pesticide to suppress the pathogen to gain appropriate yield (Gianessi et al., 2006). Pea growers are using fungicides excessively without being knowledge of chemical composition and application methods against this soil borne pathogen and this practice is harmful to farmer economy besides environmental hazard without giving results. So, there was dire need of this research to identify the effective fungicides and proper application method against wilt causing fungal pathogen.

Thus, present study was designed to assess the different fungicidal composition readily available in the market and methods of fungicides application for their efficacy against Fusarium oxysporum f. sp. pisi in laboratory and green house conditions.

\section{MATERIAL AND METHODS}

Sampling and characterization of pathogen: Pea plants which were showing symptoms of Fusarium wilt were collected from Sahiwal region of Pakistan to isolate fungal pathogen. Disease causing pathogen was isolated from root samples showing vascular discoloration symptoms. Root sections (1-2cm long) of pea plant were rinsed with distilled water. After surface sterilization with $5 \%$ sodium hypochlorite (for $2 \mathrm{~min}$ ), pieces were thoroughly rinsed two times with double distilled water. Root sections were dried on sterilize filter paper and transferred on potato dextrose agar containing petri plates. The plates were incubated for 7 days at $24-25^{\circ} \mathrm{C}$. Pure fungal isolates were obtained by transferring agar

Table 1. Fungicides used in this study; trade name, chemical name and active ingredient of fungicides.

\begin{tabular}{llll}
\hline Trade name & Chemical name & Active ingredient & References \\
\hline Fosetyl Aluminium & Fosetyl Aluminium & 80\% Fosetyl Aluminium & (Brown et al., 2004) \\
Thiophanate methyl & Thiophanate methyl & 70\% Thiophanate methyl & (Everts et al., 2014) \\
Metalaxyl+Mancozeb & Metalaxyl+Mancozeb & Metalaxyl 8\%+Mancozeb 64\% & (Singh et al., 2011) \\
Acrobate & Acrobate & Dimetho morph 9\%+Mancozeb 60\% & (Maitlo et al., 2014) \\
\hline
\end{tabular}

plugs to freshly prepared PDA plates. Morphological identification of pathogen was performed by microscopic observation. The fungal isolates were also characterized by using ITS1 based analysis. The virulent isolate SLH-08 was selected for further study.

Pathogenicity test: A pea variety (Alina) was selected for further experiments. The seeds of pea was surface sterilized with $2 \%$ sodium hypochlorite (for $2 \mathrm{~min}$ ) following by two washing with sterile distilled water. Invitro and in-vivo experiments were conducted to perform pathogenicity assay. In plate assay seeds were grown on moistened sterilized filter paper. After seedling germination $2 \mathrm{~mm}$ mycelia plug of pathogen was provided as inoculum. After 7 days of inoculation disease incidence was recorded. During pot assay sterilized pea seeds were sown in sterilized soil. When plants reached at 3-4 leaflets $5 \mathrm{~mm}$ mycelia plug of 7 days old pathogen culture was inoculated at two opposite corners of pot. The disease incidence was scored after fifteen days of inoculation.

In-vitro evaluation of fungicides against pathogen: Four different fungicides (Acrobate, Metalyxal, Fosetyl aluminium and Thiophanat) were tested at three different concentrations (5ppm, 10ppm and 15ppm) to name, chemical name and active ingredient are presented in (Table 1). For the determination of inhibition effect of fungicides; pathogen was grown on PDA amended different concentrations of fungicides in petri plates and $3 \mathrm{~mm}$ mycelial plug of pathogen was transferred at the centre of PDA plate. Control plates were without any amendment of fungicide. Plates were transferred into incubator for seven days at $24^{\circ} \mathrm{C}$. After 7 days of incubation, fungal colony diameter on fungicide containing PDA plates was recorded and compared to pathogen growth in control plates. Three replicates for each fungicide and treatment were tested and data was analyzed statistically by using CRD. The best evaluated concentration for all treatments will be used in further experiments. evaluate against Fusarium wilt of pea. Fungicide trade 


\section{Screening house assessment of fungicides} application methods: Healthy pea seeds were selected and surface sterilized with $2 \%$ sodium hypochlorite (for $2 \mathrm{~min}$ ) followed by thoroughly rinsed two times with double distilled water. Fungicides were applied by three different methods to evaluate the affective method for their action. Seeds were treated with $2 \mathrm{~g} / \mathrm{kg}$ concentration with each fungicide. Seeds were treated 23 min with each fungicide for the seed coating. PVC pots were used in the assay with $250 \mathrm{~g}$ sterilized soil filled in each pots. Three seeds were sown in each pot and mycelial plug of pathogen culture of $3 \mathrm{~mm}$ diameter was placed in the centre of seeds. Soil moisture was maintained upto $15 \%$ and pots were covered with polyethylene sheet to retain moisture. After fifteen days of germination, data of disease incidence, and plant traits was recorded. The experiment was setup by using three replicates for each treatment and control.

The most effective concentration evaluated during plate assay was selected in flooding and spraying treatment of pot assay. The untreated healthy seeds were sown in sterilized soil and flooding and spray application of fungicides were applied when plants reached 4-5 leaflet stage. The fungal inoculum was provided as agar plug in the center of pot one day prior to application of fungicides. The experiment was designed with three replicates for each treatment and control to test the suitable fungicide against wilt disease of pea.

\section{DATA ANALYSIS}

All data was analyzed statistically by using complete randomized design. Mean values of data were compared by LSD test by using $\mathrm{p}=0.05$. All statistical analysis was conducted by using statistical software SPSS.
RESULTS

Isolation and characterization of pathogen: Morphological identification of Fusarium oxysporum was conducted by following the Gerlach and Nirenberg (1982). Colony color of pathogen was whitish; substrate color was whitish to creamy in color. Microscopic observation showed the formation of abundant, thin walled and straight to crescent asexual microconidia formation on mycelia. Sexual stage of Fusarium was not observed. The sequence of the isolate SLH-08 was analyzed and submitted to NCBI database under accession no. MH379671. The results confirmed the presence and virulence of Fusarium oxysporum f. sp. pisi on pea causing wilt disease.

Pathogenic virulence of Fusarium on peas: Disease causing pathogen was isolated from the roots of pea plant wilted in infested field. Pathogenicity test of isolate was confirmed on pea variety 'Alina' during plate assay and pot assay. In plate assay, the symptoms appearance was started after $24 \mathrm{hrs}$ of inoculation and root discoloration and destruction was noted after seven days of inoculums (Figure 1). The pathogen infected the vascular bundle and discoloration symptoms were observed on pea seedlings. During pot assay, the plants started to wilt after five days of inoculum and total plant wilting was appeared on fifteen days of pathogen inoculation. During early stages of infection, yellowing and wilting of lower leaves were started and plants showed stunted growth. The pathogen was fully established with passage of time and wilting of all seedlings was observed. Pathogen was re-isolated from discolored vascular tissues of plant root and pure isolates were confirmed by morphological observations (Figure 3).

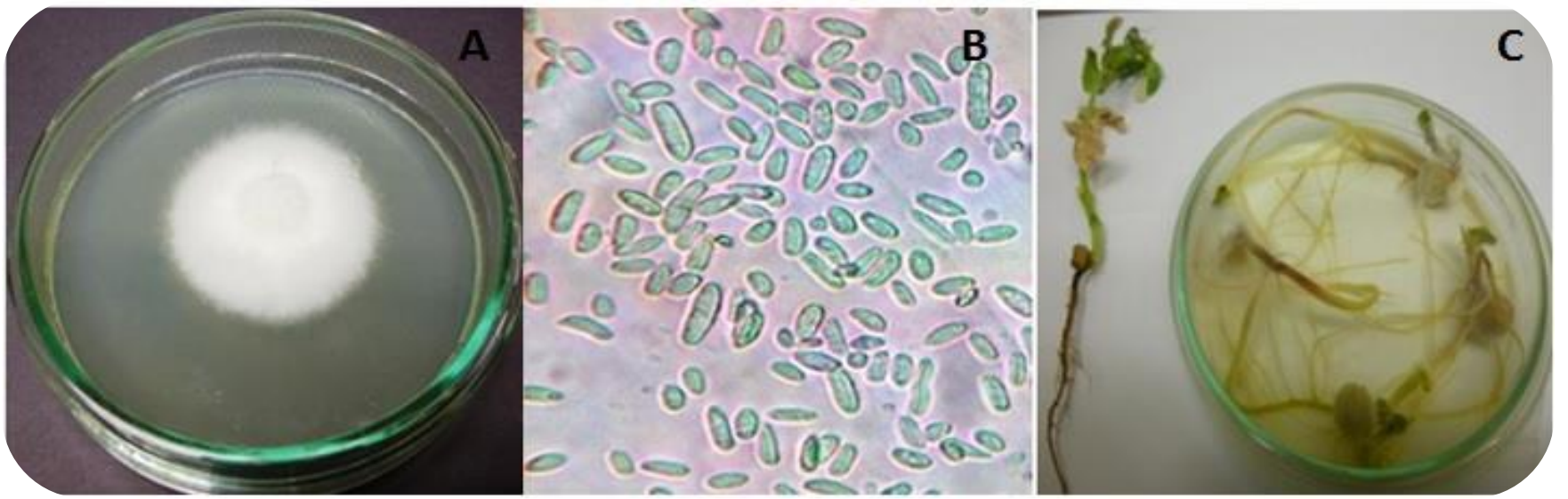

Figure 1. Colony morphology and pathogenicity assay of Fusarium oxysporum f. sp. pisi (A) Colony growth and color of Fusarium oxysporum f. sp. pisi (B) micro-conidia of Fusarium oxysporum f. sp. pisi (C) Pathogenecity assay on pea plant root and germinating seedlings in plate assay. 


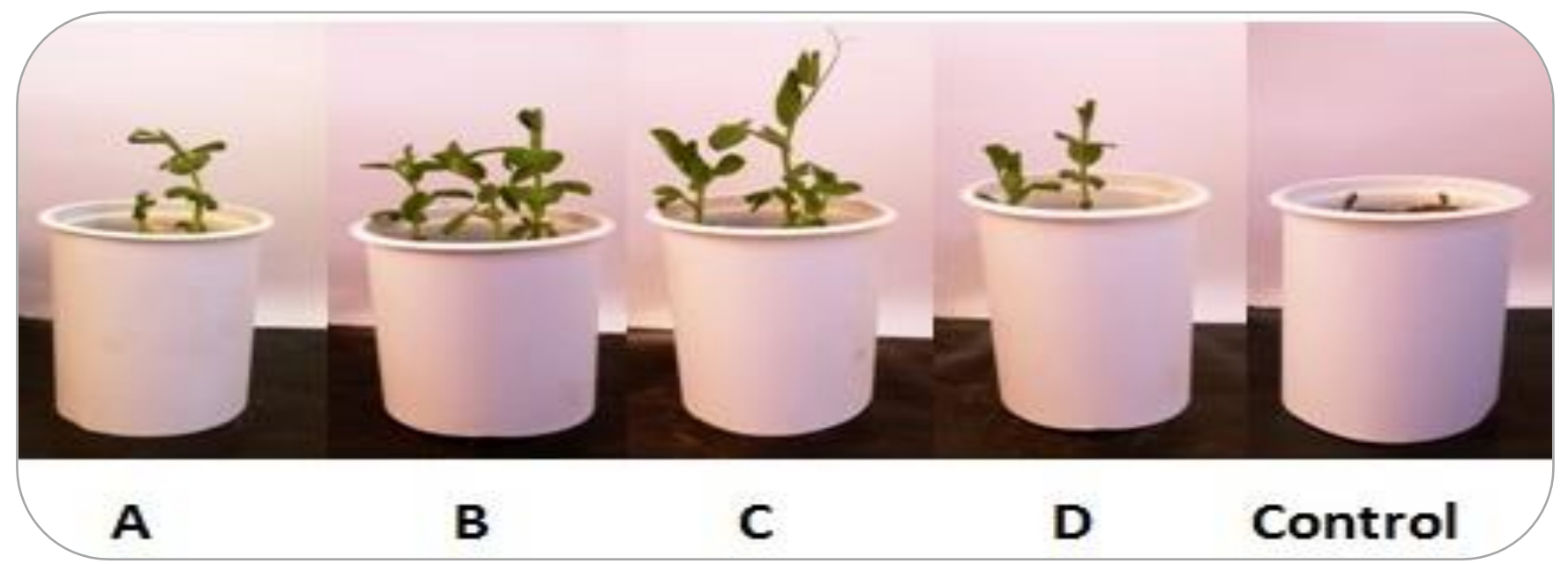

Figure 3. Response of different fungicides by seed treatment on disease incidence and plant health (A; Acrobate), (B; Fosetyl aluminium), (C; Matalyxal) and (D; Thiophanate methyl).

In-vitro evaluation of fungicides against Fusarium concentration. Thiophanate was observed most wilt: Four fungicides (Acrobate, Metalyxal, Fosetyl aluminium, Thiophanate) were evaluated by using food poison technique in plate assay under different concentrations against pea wilt causing pathogen Fusarium oxysporum. All the tested concentrations of fungicides showed suppression of pathogen and 10ppm concentration inhibited the pathogen significantly in all treatments. Metalyxal and thiophanate showed effective to inhibit Fusarium oxysporum in plate assay as compared to other fungicides. It showed hundred percent mycelial inhibition of fungus under all concentration. Furthermore, Metalyxal and Acrobat performance was significatly good at high concentrations as compare to the Fosetyl aluminium and control. The data of colony diameter of pathogenic strain was measured under all treatments and showed complete mycelial growth inhibition at $10 \mathrm{ppm}$ in (Figure. 2).

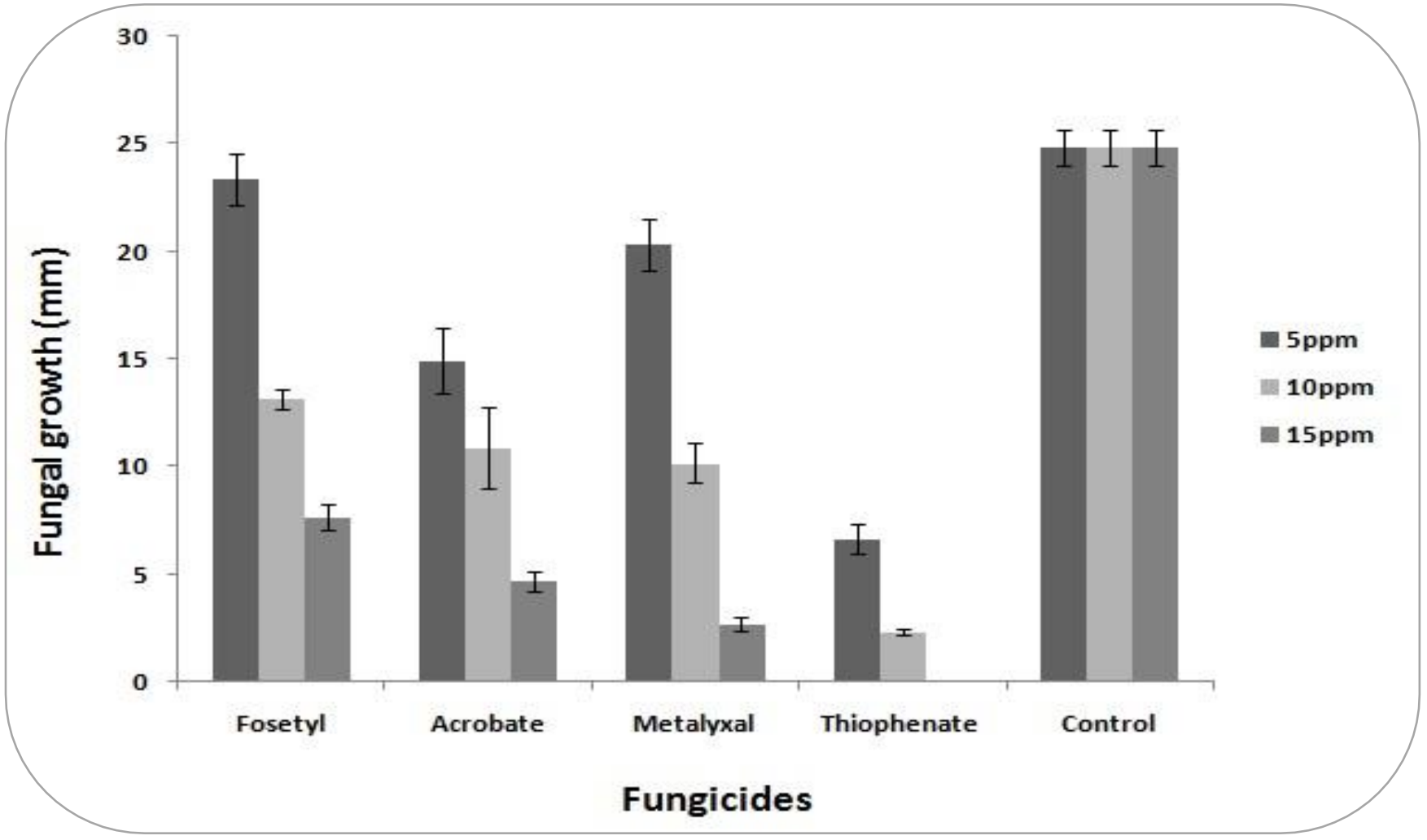

Figure 2. Effect on fungal colony growth by using different concentration of different fungicides at $7 \mathrm{dpi}$. 
Effective fungicides and application method against pea wilt: The fungicides were evaluated under green house conditions by using different application methods such as, seed treatment, soil flooding method and plant spraying method. During seed treatment, fungicides showed varied degree of pathogen inhibition and disease incidence was minimum in Fosetyl aluminium (22\%) followed by matalyxal (44.33\%), acrobate $(55.66 \%)$ and thiophanate $(66.66 \%)$ at $10 \mathrm{ppm}$ level of concentration (Figure 4). The untreated plants showed symptoms of damping off, yellowing and wilting with hundred percent disease incidence as compare the seed treated plants (Figure 3). It was observed that root shoot length and root shoot weight was significantly influenced by the application of fungicides as compared to control plants (Figure 4). The soil flooding treatment was the most suitable of application to control pea wilt disease during pot assay. All the fungicides showed good responses and no plant mortality was seen during the experiment. The fungal infection was recorded minimum in the case of acrobate treatment with disease incidence of $11 \%$ followed by thiophanate methyl $22.33 \%$, Fosetyl
44.33\% and matalyxal 55.66\% (Figure 5). The vegetative growth parameters of treated and untreated plants which include root shoot length and root shoot weight were also compared and significant improvement was observed with fungicides treatment (Figure 5). Results proved that thiophanate methyl showed high efficacy against wilt disease of pea in case of growth parameters and disease incidence during soil flooding method. The plant spraying method against Fusarium wilt of pea during green house assay also showed significant results by inhibiting the pathogen and improved plant health. By using the spraying method with $10 \mathrm{ppm}$ concentration of all fungicides, it was observed that Fosetyl aluminium treatment provided minimum disease incidence as $11 \%$ followed by matalyxal $33.33 \%$, thiophanate $55.33 \%$ and acrobate $55.66 \%$ (Figure 6). The untreated plants were infected severely and showed hundred percent diseased incidence. Root shoot length and root shoot weight was higher with the thiophanate methyl treatment as compared to other fungicidal treatment and untreated plants (Figure 6).

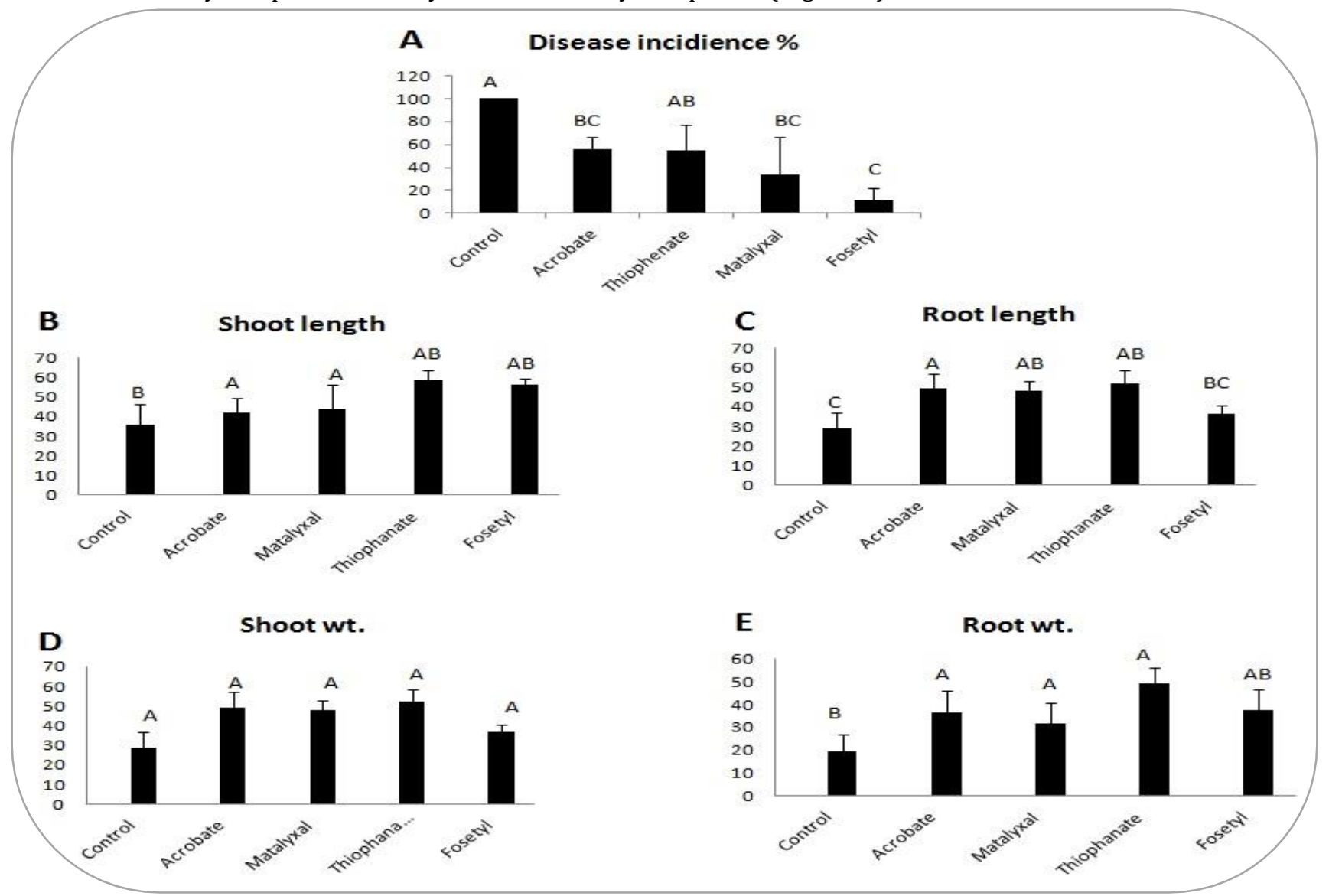

Figure 4. Effects of seed treatment with different fungicides on the disease incidence and plant growth parameters. 


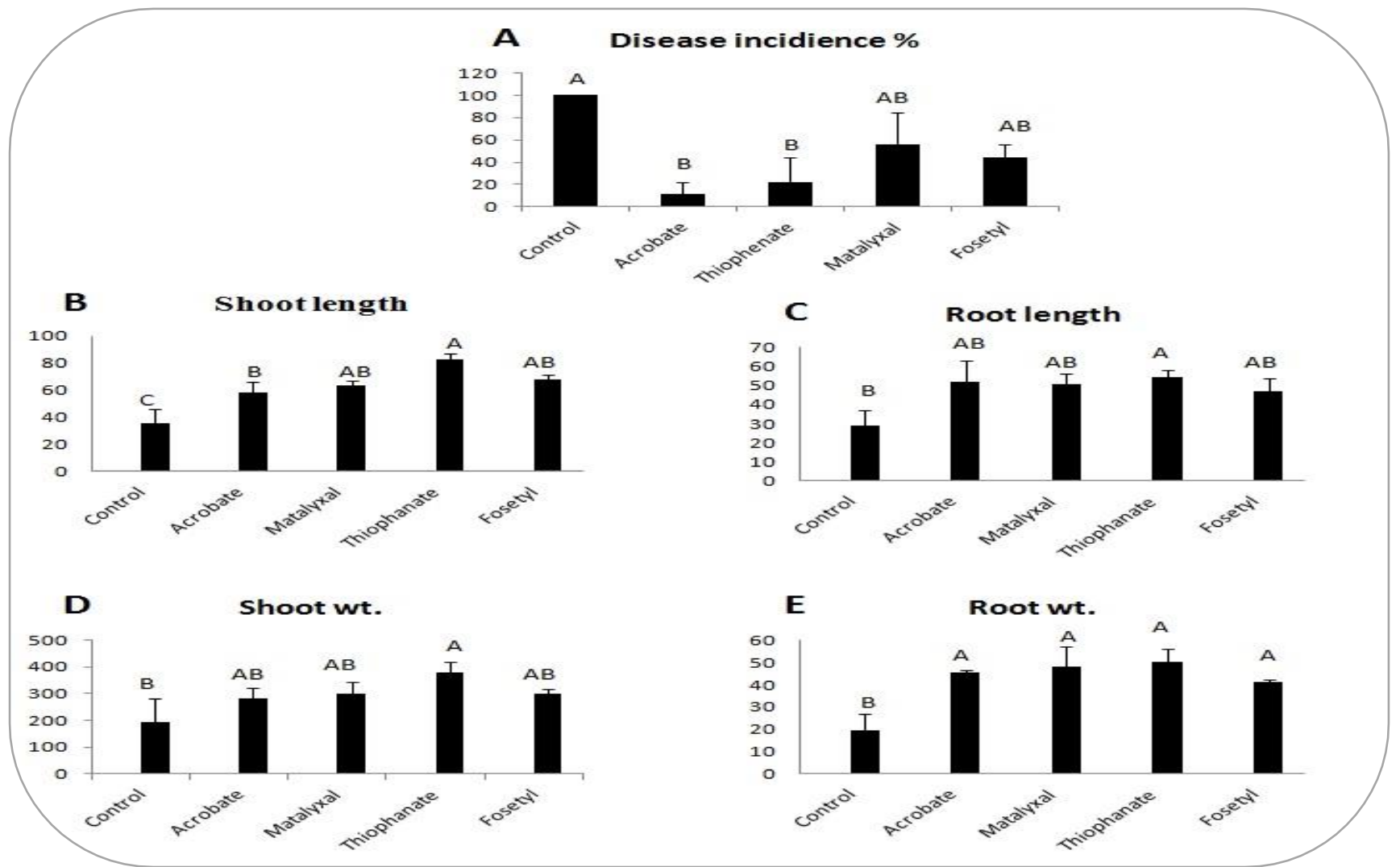

Figure 5. Response of fungicides by utilizing flooding method on Fusarium wilt incidence and plant growth properties.

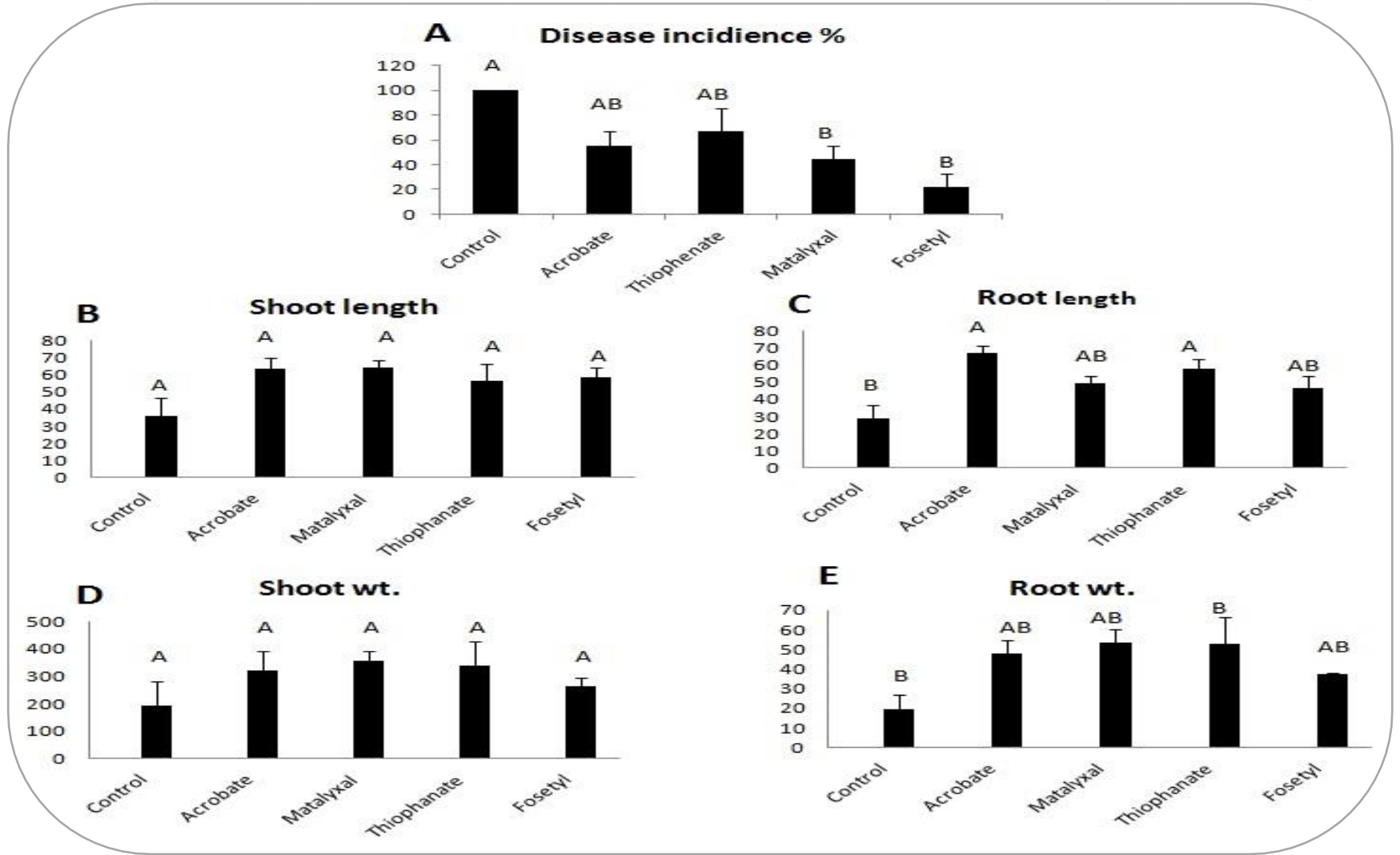

Figure 6. The utilization of spraying method of fungicides on disease suppression and plant growth parameters. 
In this study, different commercial fungicides and application methods were evaluated against Fusarium wilt of pea. The evaluation results showed that soil flooding method is most effective approach to manage this pathogen by using appropriate fungicidal concentrations. Moreover, Fosetyl aluminium showed minimum disease incidence of $11 \%$ during seed treatment and spraying method but during flooding method Acrobate showed more fruitful result in disease suppression.

\section{DISCUSSION}

The plant pathogens are contributing significantly to limit the production of crops and threat to food security. The control of plant diseases with the help of fungicides have been proved most effective and reliable strategy in spite of health hazard effects and environmental pollution. Different fungicides (Acrobate, Metalyxal, Fosetyl aluminium and Thiophanat) with various concentrations of 5.10 and $15 \mathrm{ppm}$ were evaluated against Fusarium oxysporun causing pea wilt disease during in vitro assays and green house pot trials. The concentration of $10 \mathrm{ppm}$ of all fungicides was proved more effective to inhibit the colony development and mycelial growth of fungus. A correlation between the concentrations of fungicides and pathogen inhibition rate was observed. As we increased concentration of fungicides, mycelial inhibition also increased. Matalyxal and thiophanate at $10 \mathrm{ppm}$ concentration completely inhibited the sporulation and mycelial growth of Fusarium oxysporum f. sp. pisi. The evaluation of different fungicides against Fusarium oxysporum f.sp. ciceri by using only $5 \mathrm{ppm}$ concentration was reported and fungicides provided more than $90 \%$ mycelial reduction (Subhani et al., 2011). Systematic and non-systematic fungicides were evaluated against Fusarium oxysporum f.sp. ciceri by adoting different concentrations under invitro conditions and significantly reduced fungal growth (Khan et al., 2012). Fungicides and plant extracts also proved to inhibit the Fusarium oxysporum and Curvularia lunata pathogens at different concentrations (Mamun et al., 2016).

The concentrations applied in control conditions which totally inhibited the growth rate of fungus were further evaluated in green house pot assay by utilizing different application methods. During the pot assays $10 \mathrm{ppm}$ concentration of evaluated fungicides such as; Fosetyl, Thiophanate, Matalyxal and Acrobate were tested for seed treatment, soil flooding and plant spraying method. The fungicidal treatments by using different methods proved to inhibit the growth of Fusarium oxysporum f. sp. pisi and improved plant health. By increasing the concentration of some fungicides, phytotoxic effects were observed and cease the vegetative growth of the plant (Maitlo et al., 2014). During seed dressing, results revealed that fosetyl worked efficiently to dissuade the pathogen and enhance the overall vegetative parameters of the plant. Matalyxal and mencozeb followed by thiophante and acrobate also showed remarkable effect on disease incidence. Singh et al., (2011) also reported that mancozeb completely inhibit the sporulation of Fusarium oxysporum f. sp. pisi. By taking into account, the flooding method of fungicides, it was observed that acrobate and thiophanate have ability to inhibit the mycelial growth of Fusarium oxysporum f. sp. pisi. The significant improvement of plant growth parameters showed the effective treatment of thiophanate methyl. Everts et al., (2014) and Maitlo et al., (2014) concluded that thiophanate methyl has efficacy to inhibit hundred percent Fusarium oxysporum f. sp. pisi during green house assay. Results of spraying treatment of fungicides declared that fosetyl and matalyxal proved treatment efficacy followed by acrobate and thiophanate for disease incidence of Fusarium wilt of pea. Although flooding method of fungicides showed most promising results and suppressed the growth of Fusarium oxysporum f. sp. pisi and subsequently increased all growth parameters of plants. Kamdi et al., (2012) and Subhani et al., (2011) also evaluated the fungicides and observed that fungicides work effectively against wilt disease caused by Fusarium oxysporum and obtained maximum yield of plant.

\section{REFERENCES}

Dubey, S. C., M. Suresh and B. Singh. 2007. Evaluation of Trichoderma species against Fusarium oxysporum f. sp. ciceris for integrated management of chickpea wilt. Biological Control, 40: 118-127.

Everts, K. L., D. S. Egel, D. Langston and X.-G. Zhou. 2014. Chemical management of Fusarium wilt of watermelon. Crop Protection, 66: 114-119.

Foyer, C. H., H.-M. Lam, H. T. Nguyen, K. H. Siddique, R. K. Varshney, T. D. Colmer, W. Cowling, H. Bramley, T. A. Mori and J. M. Hodgson. 2016. Neglecting legumes has compromised human health and 
sustainable food production. Nature plants, 2: 16112.

Gerlach, W., \& Nirenberg, H. 1982. The genus Fusarium-a pictorial atlas. Mitteilungen aus der Biologischen Bundesanstalt fur Land-und Forstwirtschaft Berlin-Dahlem, (209).

Gianessi, L. and N. Reigner. 2006. The Importance of Fungicides in U.S. Crop Production. Outlooks on Pest Management, 17: 209-213.

Kamdi, D., M. Mondhe and G. Jadesha. 2012. Efficacy of botanicals, bio-agents and fungicides against Fusarium oxysporum F. Sp. Ciceri, in chickpea wilt sick plot. Annals of Biological Research, 3: 53905392.

Khan, H., M. Saifulla, A. Nawaz, P. Somashekharappa and R. Rafiulla. 2012. Efficacy of fungicides and biocontrol agents against Fusarium oxysporum f. sp. ciceri causing wilt of chickpea. Environment and Ecology, 30: 570-572.

Maitlo, S., R. Syed, M. Rustamani, R. Khuhro and A. Lodhi. 2014. Comparative efficacy of different fungicides against fusarium wilt of chickpea (Cicer arietinum L.). Pakistan Journal of Botany, 46: 2305-2312.

Mamun, M., S. Shamsi and M. Bashar. 2016. In vitro evaluation of fungicides and plant extracts against pathogenic fungi of jute seeds. Bioresearch Communications, 2: 189-192.

Moosa, A., Sahi, S. T., Haq, I. U., Farzand, A., Khan, S. A., \& Javaid, K. 2017. Antagonistic potential of Trichoderma isolates and manures against Fusarium wilt of tomato.International journal of vegetable science, 23(3), 207-218.
Persson, L., L. Bødker and M. Larsson-Wikström. 1997. Prevalence and pathogenicity of foot and root rot pathogens of pea in Southern Scandinavia. Plant disease, 81: 171-174.

Sharma, P. 2011. Alarming occurrence of Fusarium wilt disease in pea (Pisum sativum L.) cultivations of Jabalpur district in Central India revealed by an array of pathogenicity tests. Agriculture and Biology Journal of North America, 2(6), 981-994.

Sharma, S.K., Ramesh, A., Sharma, M.P., Joshi, O.P., Govaerts, B., Steenwerth, K.L. and Karlen, D.L., 2010. Microbial community structure and diversity as indicators for evaluating soil quality. In Biodiversity, biofuels, agroforestry and conservation agriculture, 4:317-358.

Singh, A. K. and H. S. Chhatpar. 2011. Combined use of Streptomyces sp. A6 and chemical fungicides against fusarium wilt of Cajanus cajan may reduce the dosage of fungicides required in the field. Crop Protection, 30: 770-775.

Subhani, M. N., S. T. Sahi, S. Hussain, A. Ali, J. Iqbal and K. Hameed. 2011. Evaluation of various fungicides for the control of gram wilt caused by Fusarium oxysporium f. sp. ciceris. African Journal of Agricultural Research, 6: 4555-4559.

Urbano, G., P. Aranda, E. Gómez-Villalva, S. Frejnagel, J. M. Porres, J. Frías, C. Vidal-Valverde and M. LópezJurado. 2003. Nutritional Evaluation of Pea (Pisum sativum L.) Protein Diets after Mild Hydrothermal Treatment and with and without Added Phytase. Journal of Agricultural and Food Chemistry, 51: 2415-2420. 